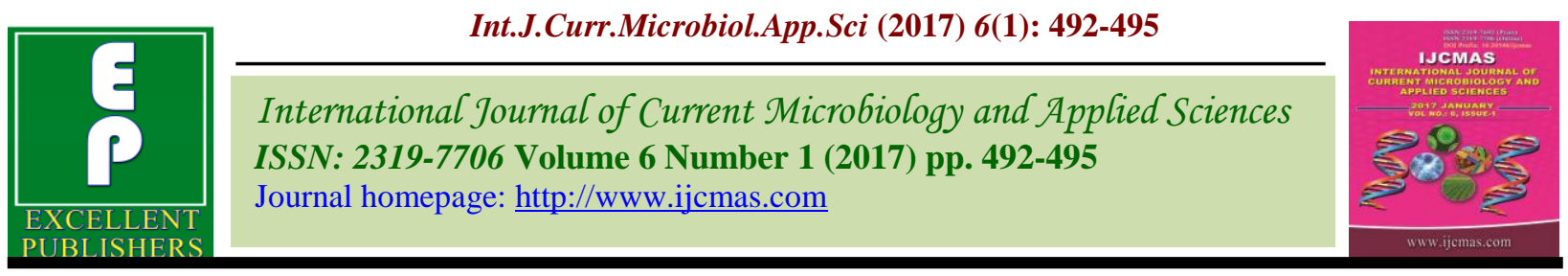

Original Research Article

http://dx.doi.org/10.20546/ijcmas.2017.601.058

\title{
Cross-sectional Study of Hand Hygiene Practices and Comparison of Microbial Flora of Dominant and Non-dominant Hand amongst Health Care Personnel
}

\author{
Vrushali V. Kulkarni ${ }^{1 *}$, Poorva A. Sule ${ }^{2}$, Ganesh T. Shinde ${ }^{3}$ and S. Kartikeyan ${ }^{1}$ \\ ${ }^{1}$ Department of Community Medicine, ${ }^{2}$ Department of Microbiology, ${ }^{3}$ Rajiv Gandhi Medical \\ College, Kalwa, Thane, Maharashtra, India \\ *Corresponding author
}

\section{A B S T R A C T}

Keywords

Health care personnel, Hand washing, Dominant and non-dominant hands, Microbial flora.

Article Info

Accepted:

23 December 2016 Available Online: 10 January 2017
Hand hygiene is considered as the most effective method of controlling health care related infections. The present study was conducted to determine the awareness of hand washing among Health care personnel (HCP) and to compare the microbial flora of dominant and non-dominant hands of HCP. Sixty-nine HCP were interviewed using a pre-validated questionnaire regarding compliance of hand washing practices. Their dominant hand was noted. Using the sterile pre-moistened swab sticks sample was collected from both hands of HCP and cultivated on Blood Agar. Colony Forming Units counting and identification of bacteria was done. Participants who were aware of hand washing technique and hand washing guidelines comprised $97.10 \%$ and $85.5 \%$, respectively. Out of all, $63.76 \%$ had received training in hand washing. The frequency of hand washing was four times or more for $49(71.01 \%)$. Posters and information charts available in the hospital were the major sources $(85.5 \%)$ of information on hand washing. Though there is strong awareness regarding hand-washing among healthcare workers, the compliance is inadequate. There was no significant difference in the microbial flora of dominant and non-dominant hands of health-care personnel.

\section{Introduction}

Hand hygiene is the most effective measure for interrupting the transmission of microorganisms, which cause infection both in the community and in the healthcare setting (Jumma, 2005). Healthcare-associated infections (HAI) occur both in the developed and less developed nations (Saleem et al., 2012) and are considered to be spread by the hands of health care personnel (HCP) through direct contact (Paul et al., 2011; Pittet et al., 2000). Despite the efficacy of hand cleansing in removal of transient bacteria, the hands of HCP have been frequently incriminated as vehicles of transmission of nosocomial pathogens (McNeil et al., 2014). The present study was conducted to determine the awareness of hand washing among HCP and to compare the microbial flora of dominant and non-dominant hands of HCP.

\section{Materials and Methods}

This comparative, cross-sectional, prospective study was conducted at Rajiv Gandhi Medical College and Chhatrapati Shivaji Maharaj Hospital, Kalwa, Thane (Maharashtra, India) 
over a period of three months. After obtaining permission from the Institutional Ethics Committee, HCP who gave written informed consent to participate in the study were interviewed using a pre-validated questionnaire wherein their dominant hand (right or left) and compliance of HCPs to the "My five moments of hand hygiene" recommendation of the World Health Organization (WHO, 2009) was also recorded.

\section{Sample collection and processing}

Sterile pre-moistened swabs were rubbed over palm including the inter-digital spaces and fingertips of both dominant and non-dominant hands. The swabs were cultured on blood agar and plates were incubated at $37^{\circ} \mathrm{C}$ for $24 \mathrm{hr}$. The growth of various bacteria and fungi, if any, was studied in terms of colony characteristics and colony forming units (CFU). Further identification was done by Gram staining and biochemical reactions (Collee et al., 2006).

Dominant (right hand of the right-handed persons and left hand of left-handed persons) hands formed the first group and nondominant (the remaining hands) the second group. The number of CFU on dominant and non-dominant hands was statistically analysed.

\section{Observations}

The participants $(n=69$; males $=22,31.88 \%$; females $=47,68.12 \%$ ) comprised medical students $\quad(n=20 ; 28.98 \%)$, nurses $\quad(n=19$; $27.53 \%)$, houseman $(\mathrm{n}=04 ; 05.79 \%)$, interns $(\mathrm{n}=09 ; 13.04 \%), \quad$ laboratory technicians $(\mathrm{n}=13 ; 18.84 \%)$ and attendants $(\mathrm{n}=04$; $05.79 \%)$. Their ages aged from 18 yrs to 56 yrs (mean=30 yrs; SD = 11.3 yrs: Confidence Interval $=27.279$ to 32.721 yrs). Participants who were aware of hand washing technique and hand washing guidelines (WHO, 2009) comprised $97.10 \%$ and $85.5 \%$, respectively. Out of all, $63.76 \%$ were trained in hand washing (WHO, 2009).

Compliance of hand washing practices to WHO's "My five moments of hand hygiene" is outlined in the Table. The frequency of hand washing was three times or less per day among $20(28.98 \%)$ respondents while it was four times or more for $49(71.01 \%)$. Posters and information charts available in the hospital were the major sources $(85.5 \%)$ of information on hand washing.

In 63 participants, right side was dominant and in remaining 6 participants, left side was dominant. In 28 (40.57\%), dominant hands had more CFUs while the reverse was observed in $33(47.82 \%)$ participants. However, in 8 (11.6\%) HCPs, the number of CFUs on dominant and non-dominant hands were the same. There was no significant difference in average colony forming units on dominant and non-dominant hand $(\mathrm{p}=0.838119)$.

CFUs of Staphylococcus aureus were more on the dominant hand as compared to that on the non-dominant in $24(34.78 \%)$ while the reverse was observed in $32(46.38 \%)$ of HCPs. In $13(18.84 \%)$ HCWs, the number of CFUs of Staphylococcus aureus on dominant and non-dominant hands were same. There was no significant difference in average CFU of Staphylococcus aureus on dominant and non dominant hand $(\mathrm{p}=0.844062)$.

\section{Results and Discussion}

Hand hygiene is known to prevent crossinfection in health care settings and though many countries have hand hygiene guidelines for healthcare settings, the overall compliance among HCPs is unsatisfactory (Christiaens et al., 2006; Wendt, 2001). 
Studies on hand hygiene have been chiefly observational and may be subject to observer bias. Blinding, randomization and controlling for confounding variables may not be feasible (Curtis et al., 2003). In the healthcare setting, there is a dichotomy between knowledge and behaviour as regards hand hygiene (Jumma, 2005). There is evidence that HCPs may be unaware of their poor compliance, but other factors result in non-adherence (O'Boyle et al., 2001). In the current study, though the awareness about hand-washing was $97.10 \%$, the compliance was in range of 41-69\%.

Handedness has a significant $(\mathrm{p}<0.001)$ influence in bacterial communities (Fierer $e t$ al., 2008). The influence of handedness on bacterial communities on the palm is likely due either to differences in skin environmental conditions (such as, sebum production, salinity, hydration) or to the dominant hand coming into contact with different types of environmental surfaces, as compared to the non-dominant hand.

Table Compliance to "Five moments of hand hygiene" among health care personnel $(n=69)$

\begin{tabular}{|l|c|c|c|c|}
\hline $\begin{array}{l}\text { "Five moments of hand } \\
\text { hygiene" }\end{array}$ & Compliant & $\begin{array}{c}\text { Not } \\
\text { compliant }\end{array}$ & $\begin{array}{c}\text { SEDP } \\
\text { value \# }\end{array}$ & p value \\
\hline Before touching patient & $41(59.42)$ & $28(40.58)$ & 8.3601 & 0.0121 \\
\hline Before aseptic procedures & $41(59.42)$ & $28(40.58)$ & 8.3601 & 0.0121 \\
\hline $\begin{array}{l}\text { After touching body fluid or } \\
\text { waste }\end{array}$ & $48(69.56)$ & $21(30.43)$ & 7.8338 & $<0.00001$ \\
\hline After touching a patient & $36(52.17)$ & $33(47.83)$ & 8.5045 & 0.30460 \\
\hline $\begin{array}{l}\text { After touching patient } \\
\text { surroundings }\end{array}$ & $32(46.37)$ & $37(53.62)$ & 8.4902 & 0.19683 \\
\hline
\end{tabular}

Figures in parentheses indicate percentages

\# Standard error of difference between two proportions

The bacterial communities on left and right hands from the same individual were more similar than expected. Dominant hands have similar overall levels of diversity as nondominant hands but the composition of the bacterial communities on dominant and nondominant hands from the same individual was significantly different (Fierer et al., 2008). In current study there was no significant difference in the total CFU or CFU of the pathogen Staphylococcus aureus in dominant and non-dominant hands. Similarly, a study on subungual flora found no significant difference in mean CFU between the right and left hands of each subject (McGinley et al., 1988).

\section{Limitations}

The spot surveillance of hand washing activity could have been significant instead of questionnaire. But that too may not be considered as reliable method of data collection as behaviour alteration in presence of observer is possible.

In conclusion, though there is strong awareness regarding hand-washing among healthcare workers, the compliance is inadequate. There was no significant difference in the microbial flora of dominant and non-dominant hands of health-care personnel.

Acknowledgements: This study was conducted as part of ICMR-STS 2014. The authors thank the Head and all staff of the Department of Microbiology, Rajiv Gandhi Medical College and Chhatrapati Shivaji Maharaj Hospital, Kalwa, Thane (Maharashtra, India) for their cooperation. 


\section{References}

Christiaens, G., Barbier, C., Mutsers, J., Warnotte, J., De Mol, P., Bouffioux, C. 2006. Hand hygiene: first measures to control nosocomial infection. Rev Med Liege, 61(1): 31-36. Available at: https://www.ncbi.nlm.nih.gov/pubmed/164 91546 Accessed on: 14 Nov 2016 (Original article is in French)

Collee, J.G., Miles, R.S., Watt, B. 2006. Tests for identification of bacteria. In: Collee, J.G., Fraser, A.G., Marmion, B.P., Simmons, A (Eds.) Mackie \& McCartney's Practical Medical Microbiology. 14th ed. Churchill Livingstone, London, pp.131-149.

Curtis, V., Biran, A., Deverell, K., Hughes, C., Bellamy, K., Drasar, B. 2003. Hygiene in the home: relating bugs and behaviour. Soc. Sci. Med., 57: 657-672.

Fierer, N., Hamady, M., Lauber, C.L., Knight, R. 2008. The influence of sex, handedness and washing on the diversity of hand surface bacteria. Proc. Natl. Acad. Sci. USA, 105(46):17994-17999. Available at: https://www.ncbi.nlm.nih.gov/pmc/articles/ PMC2584711/ Accessed on: 14 Nov 2016.

Jumaa, P.A. 2005. Hand hygiene: simple and complex. Int. J. Infect. Dis., 9(1); 3-14.

McGinley, K.J., Larson, E.L., Leyden, J.J. 1988. Composition and density of microflora in the subungual space of the hand. J. Clin. Microbiol., 26(5): 950-953.

McNeil, S.A., Foster, C.L., Hedderwick, S.A., Kauffman, C.A. 2001. Effect of Hand cleansing with antimicrobial soap or alcohol based gel on Microbial colonization of artificial fingernails worn by health care workers. Clin. Infect. Dis., 32: 367-372.

O'Boyle, C.A., Henly, S.J., Larson, E. 2001. Understanding adherence to hand hygiene recommendations: the theory of planned behavior. Am. J. Infect. Control, 29: 352360.

Paul, R., Das, N.K., Dutta, R., Bandyopadhyay, R., Banerjee, A.K. 2011. Bacterial contamination of the hands of doctors: a study in the medicine and dermatology wards. Indian J. Dermatol. Venereol. Leprol., 77(3): 307-313.

Pittet, D., Hugonnet, S., Harbath, S., Mourouga, P., Sauvan, V., Touveneau, S., et al. 2000. Effectiveness of a hospital-wide programme to improve compliance with hand hygiene. Lancet, 356(9238): 13071312.

Saleem, M., Vaish, A.K., Idris, M.Z., Sonkar, A.A., Agarwal, J., Singh, M., et al. 2012. Pattern of nosocomial infection among patients admitted in medical and surgical wards of a secondary care hospital in north India - An epidemiological evaluation. Indian J. Community Health, 24(4):285-290.

Wendt, C. 2001. Hand hygiene - Comparison of international recommendations. J. Hosp. Infect., 48Suppl A: S23-28.

World Health Organization. 2009. WHO guidelines on hand hygiene in health care. First Global Patient Safety Challenge. Clean Care Is Safer Care. WHO, Geneva, pp. 24-60.

\section{How to cite this article:}

Vrushali V. Kulkarni, Poorva A. Sule, Ganesh T. Shinde and Kartikeyan, S. 2017. Crosssectional Study of Hand Hygiene Practices and Comparison of Microbial Flora of Dominant and Non-dominant Hand amongst Health Care Personnel. Int.J.Curr.Microbiol.App.Sci. 6(1): 492-495. doi: http://dx.doi.org/10.20546/ijcmas.2017.601.058 